Info Artikel Diterima Juli 2019

Disetujui September 2019

Dipublikasikan Oktober 2019

\title{
PEMANFAATAN HASIL FERMENTASI LIMBAH CAIR TEH HIJAU \\ PADA FREKUENSI PENYIRAMAN YANG BERBEDA TERHADAP \\ PERTUMBUHAN BIBIT KARET (Hevea brasiliensis Mull. Arg)
}

\section{UTILIZATION OF FERMENTED LIQUID WASTE GREEN TEA AT DIFFERENT WATERING FREQUENCIES TO THE GROWTH OF RUBBER (Hevea brasiliensis Mull. Arg) SEEDLING}

\author{
Retno Muningsih, Farhan Wardhana Majing \\ Politeknik LPP \\ Jln. LPP 1A Balapan Yogyakarta
}

Email: retnomuningsih@gmail.com, wardanaf96@gmail.com

\begin{abstract}
This research aimed to know the differences influence the frequency of watering fermentation liquid waste green tea on early growth of rubber plant seed. This research method using Randomized Complete Block Design (RCBD) non factorial, i.e. the granting of fermentation liquid waste green tea with a dose of 10 $\mathrm{ml} /$ poly bag with 3 treatment. As for the extent of the treatments given are control (P0), the frequency of watering every two weeks (P2), the frequency of watering every four weeks (P4). Each treatment was repeated five times so that there are 15 units of the experiment. Each unit is comprised of 1 trial crops so that there is a total of 15 plants. The giving of liquid organic fertilizer from waste liquid fermented green tea can enhance plant growth include rubber, i.e. plant height, number of leaves, green leaves, heavy wet and dry long \& root plant rubber. On treatment of P2 (the frequency of watering every two weeks) show the highest results and good than P0 treatment (control) and P4 (the frequency of watering every four weeks).
\end{abstract}

Keywords: fermentation, tea liquid waste, liquid organic fertilizer.

\begin{abstract}
ABSTRAK
Penelitian ini bertujuan untuk mengetahui perbedaan pengaruh frekuensi penyiraman fermentasi limbah cair teh hijau pada pertumbuhan awal bibit tanaman karet. Penelitian ini menggunakan metode Rancangan Acak Kelompok (RAK) non faktorial, yaitu pemberian fermentasi limbah cair teh hijau dengan dosis $10 \mathrm{ml} /$ polybag dengan 3 perlakuan. Adapun taraf perlakuan yang diberikan adalah kontrol (P0), penyiraman 2 minggu sekali (P2), penyiraman 4 minggu sekali (P4). Setiap perlakuan diulang lima kali sehingga terdapat 15 satuan percobaan. Setiap unit percobaan terdiri dari 1 tanaman sehingga total terdapat 15 tanaman. Pemberian pupuk organik cair dari limbah cair teh hijau yang terfermentasi dapat meningkatkan pertumbuhan tanaman karet, meliputi tinggi tanaman, jumlah daun, kehijauan daun, berat basah \& kering serta panjang akar tanaman karet. Pada perlakuan P2 (frekuensi penyiraman 2 minggu sekali)
\end{abstract}


menunjukkan hasil yang paling tinggi dan baik dibanding dengan perlakuan P0 (kontrol) dan P4 (frekuensi penyiraman 4 minggu sekali).

Kata kunci: fermentasi, limbah cair teh, pupuk organik cair.

\section{PENDAHULUAN}

Limbah cair adalah buangan hasil proses/sisa dari suatu kegiatan yang berwujud cair, kehadirannya pada suatu saat dan tempat tidak dikehendaki lingkungannya karena tidak mempunyai nilai ekonomis sehingga cenderung untuk dibuang. Salah satunya adalah limbah cair teh hijau. Limbah cair teh hijau masuk pada jenis limbah aktivitas manusia dalam bidang pertanian (industri pengolahan). Daun teh yang baru dipetik mengandung air $75 \%$ dari berat daun dan sisanya berupa padatan dan terdiri dari bahan organik dan anorganik. Air yang terkandung di daun dikeluarkan melalui proses pelayuan dan pengeringan dalam pengolahan teh hijau di pabrik pengolahan. Limbah cair teh hijau belum dimanfaatkan secara optimal, perlu sentuhan teknologi yang dapat mengubah limbah cair menjadi pupuk organik cair yang bermanfaat (Muningsih, et al., 2016).

Limbah cair yang telah difermentasi dapat digunakan sebagai salah satu alternatif pupuk organik yang meningkatkan kesuburan tanah dan penambahan unsur hara dalam tanah. Fermentasi limbah cair teh hijau dapat menggunakan bioaktifator sehingga bisa menjadi pupuk organik cair yang berguna sebagai tambahan unsur hara atau pengganti pupuk anorganik. Menurut Pusat Penelitian Karet Sembawa (2002), penggunaan pupuk yang berasal dari bahan kimia tidak dibenarkan pada saat pembibitan. Hal ini disebabkan karena bibit karet sangat rentan terhadap bahan kimia. Padahal pembibitan juga sangat mempengaruhi dalam produksi mendatang, maka dari itu agar bibit tanaman karet tetap berkualitas baik maka pupuk kimia digantikan dengan pupuk organik yang dapat memacu pertumbuhan bibit karet.

Menurut Purwati (2013), pemberian pupuk organik cair (POC) dengan intensitas penyiraman setiap satu mingu (P1), dua minggu, dan tiga minggu sekali pada pembibitan karet yang berumur 30, 60 dan 90 HST (hari setelah tanam) memberikan pengaruh nyata dan sangat nyata terhadap rata-rata tinggi tanaman karet, terutama pada intensitas penyiraman. Hal ini diduga unsur hara yang terdapat di dalam POC dimanfaatkan oleh tanaman terutama untuk aktivitas proses fotosintesis yang optimal guna menunjang pertumbuhan tinggi tanaman.

Menurut Tumpal et al., (2013), secara umum permasalahan utama perkebunan karet adalah masih rendahnya produktivitas tanaman karet dan tingginya tingkat kematian bibit setelah beberapa saat tanam di lapangan. Mengingat pentingnya meningkatkan produksi karet, bahan tanam merupakan salah satu faktor penting dalam menunjang produktivitas tanaman karet, sehingga perlu diperhatikan dalam proses persiapan benih sampai ke pemeliharaan bibit. Beberapa aspek yang perlu diperhatikan diantaranya :

1. Pemilihan benih dari varietas yang unggul

2. Pemeliharaan tanaman secara berkelanjutan

3. Pemberian pupuk organik, baik pupuk organik cair maupun pupuk organik padat dari bahan yang bisa dikomposkan atau limbah. 
Fermentasi limbah cair teh hijau menggunakan bioaktivator EM-4, diharapkan mampu memberikan tambahan unsur hara maupun bahan organik dalam tanah yang mudah diserap, dan juga sebagai ZPT alami, sehingga tidak menutup kemungkinan bahwa dengan pemanfaatan limbah cair teh hijau sebagai pupuk organik cair bisa meningkatkan kualitas pertumbuhan bibit tanaman karet, mengurangi tingkat kematian bibit, menjadi bahan organik alami yang pada akhirnya mampu meningkatkan produktifitas tanaman dan membantu mengurangi limbah yang berlimpah, sehingga limbah tersebut tidak akan mencemari lingkungan.

\section{BAHAN DAN METODE}

Penelitian telah dilaksanakan di Greenhouse dan kebun percobaan Politeknik LPP Yogyakarta. Penelitian ini menggunakan metode Rancangan Acak Kelompok (RAK) non faktorial, yaitu pemberian fermentasi limbah cair teh hijau dengan 3 perlakuan yaitu: Kontrol/penyiraman air 1 minggu sekali (P0), Penyiraman 2 minggu sekal, Penyiraman 4 minggu sekali. Variabel pertumbuhan yang diamati antara lain jumlah daun, tinggi tanaman, kehijauan daun, bobot basah dan bobot kering.

\section{HASIL DAN PEMBAHASAN}

Hasil penelitian bahwa aplikasi pupuk organik cair teh hijau dengan frekuensi penyiraman yang berbeda terhadap pertumbuhan bibit karet menunjukkkan bahwa tinggi tanaman, kehijauan daun, bobot kering akar dan daun menunjukkan pengaruh berbeda nyata dibandingkan dengan variabel pengamatan jumlah daun, bobot kering batang dan panjang akar tidak berbeda nyata. Hal ini disebabkan oleh beberapa faktor antara lain jenis tanah, kandungan unsur hara POC. Kandungan unsur hara dalam POC menunjukan bahwa kandungannya dibandingkan dengan Permentan No.70 masih rendah dibawah standar. POC termasuk pada pupuk yang slow realese.

Tabel 1. Hasil Analisis Limbah Cair Teh Hijau (14 Hari Setelah Fermentasi)

\begin{tabular}{lllll}
\hline Parameter & Satuan & $\begin{array}{l}\text { Hasil } \\
\text { Fermentasi }\end{array}$ & Standar mutu* & Harkat* \\
\hline C-Organik & $\%$ & 6.96 & $\min 6$ & Sedang \\
C/N rasio & - & 29.00 & $* * 15-20$ & **Tinggi \\
N total & $\%$ & 0.24 & $3-6$ & Rendah \\
P2O5 total & $\%$ & 0.07 & $3-6$ & Rendah \\
K2O total & $\%$ & 0.65 & $3-6$ & Rendah \\
S total & $\%$ & 0.03 & - & - \\
Mg total & $\%$ & 0.04 & $250-5000$ & Rendah \\
Cu total & ppm & 1.73 & $250-5000$ & Rendah \\
Zn total & ppm & 2.74 & &
\end{tabular}

Sumber : Laboratorium BPTP Yogyakarta dalam Muningsih, 2016

* Permentan No. 70/Permentan/SR.140/10/2011

** SNI 19-7030-2004 
Pada analisis kandungan hasil fermentasi limbah cair teh hijau yang telah dilakukan menunjukkan hampir secara keseluruhan kandungan yang terdapat pada hasil fermentasi limbah cair teh hijau masih berada dibawah standar mutu yang ditetapkan oleh Kementerian Pertanian yang tercantum dalam Permentan No. 70/Permentan/SR.140/10/2011. Dari 9 parameter yang telah di uji hanya terdapat 1 parameter yang sudah masuk kedalam standar mutu yang baik menurut Kementerian Pertanian. Parameter tersebut adalah kandungan Corganik pada hasil fermentasi limbah cair teh hijau. Standar kandungan Corganik pupuk cair organik menurut Kementerian Pertanian adalah minimal $6 \%$, sedangkan kandungan C-organik pada hasil fermentasi limbah cair teh hijau adalah $6,96 \%$. Nilai $\mathrm{SNI}$ untuk $\mathrm{C} / \mathrm{N}$ ratio pupuk organik cair adalah berkisar antara 15 - 20 (Badan Standar Nasional, 2004), sehingga dapat dikatakan bahwa pupuk organik yang difermantasi tersebut memiliki nilai yang tinggi (29). Nilai $\mathrm{C} / \mathrm{N}$ harus rendah karena jika nilai $\mathrm{C}$ (carbon) lebih tinggi dibandingkan nilai $\mathrm{N}$ maka dikhawatirkan unsur $\mathrm{N}$ akan merombak unsur $\mathrm{C}$ terus menerus dibandingkan tersalurkan ke tanaman.

Limbah cair teh hijau masuk pada jenis limbah aktivitas manusia dalam bidang pertanian (industri pengolahan). Daun teh yang baru dipetik mengandung air $75 \%$ dari berat daun dan sisanya berupa padatan dan terdiri dari bahan organik dan anorganik. Air yang terkandung di daun dikeluarkan melalui proses pelayuan dan pengeringan dalam pengolahan teh hijau sehingga menghasilkan limbah cair. Hasil analisa limbah cair teh menunjukkan kandungan C-Organik tinggi dan kandungan hara makro serta mikro yang rendah. Pemanfaatan limbah cair teh hijau yang terfermentasi dengan penambahan starter EM-4 dimaksudkan agar proses fermentasi pembuatan pupuk organik cair berlangsung lebih cepat dan hasil dari fermentasi ini mempunyai kelebihan dibandingkan dengan jenis pupuk lain dalam meningkatkan kesuburan tanah (Muningsih, 2016), sehingga tidak menutup kemungkinan bahwa dengan pemanfaatan limbah cair teh hijau sebagai pupuk organik cair bisa meningkatkan kualitas pertumbuhan bibit tanaman karet, mengurangi tingkat kematian bibit, menjadi bahan organik alami yang pada akhirnya mampu meningkatkan produktifitas tanaman dan membantu mengurangi limbah yang berlimpah, sehingga limbah tersebut tidak akan mencemari lingkungan.

Menurut Patanga et al., (2016), pupuk organik memiliki kelebihan dibandingkan dengan pupuk kimia, diantaranya: membuat struktur tanah menjadi gembur, kaya akan bahan organik, mengandung unsur hara paling lengkap, yakni hara makro dan mikro walaupun dalam jumlah yang kecil, memperbaiki daya serap air pada tanah dan tanaman, memperbaiki perkembangan mikroorganisme dalam tanah, dan biaya pembuatan relatif murah dan dapat dibuat sendiri. Pupuk organik cair mengandung unsur hara yang lengkap baik unsur hara makro maupun mikro sehingga sangat baik untuk memperbaiki sifat fisik dan biologi tanah, mampu meningkatkan daya serap tanah terhadap air, memperbaiki struktur tanah, serta meningkatkan ketersediaan bahan organik di dalam tanah. Namun kelemahannya kandungan unsur hara dalam pupuk organik tidak setinggi kandungan unsur hara dalam pupuk anorganik, selain itu respon tanaman terhadap aplikasi pupuk organik lebih lambat dibandingkan dengan 
aplikasi pupuk anorganik. Pupuk organik cair tergolong pupuk slow release atau sering disebut dengan pupuk lepas terkendali (controlled release).

Pengaplikasian pupuk organik cair limbah teh hijau berpengaruh nyata pada parameter tinggi tanaman. Tinggi tanaman pada perlakuan penyiraman POC 2 minggu sekali memberikan pengaruh tertinggi yaitu $46,76 \mathrm{~cm}$ tidak berbeda dengan penyiraman POC 4 minggu sekali $(44,16 \mathrm{~cm})$ sedangkan perlakuan penyiraman menggunakan air 1 minggu sekali menunjukkan hasil yang terendah $(39,54 \mathrm{~cm})$. Hal ini terjadi karena pada perlakuan penyiraman POC 2 minggu sekali kemungkinan memiliki kandungan unsur hara 2 kali lebih banyak dibandingkan pada perlakuan penyiraman POC 4 minggu sekali. Menurut Hanolo (1997) pemberian konsentrasi pupuk sedikit dan dilakukan pemupukan secara berkelanjutan lebih memberikan hasil tanaman yang memuaskan daripada pemberian pupuk organik dengan konsentrasi yang tinggi dengan interval waktu yang cukup lama. Hal ini berkaitan dengan ketersediaan dan penyerapan unsur hara, yang dapat berpengaruh terhadap lambatnya penyerapan unsur hara yang dibutuhkan tanaman.

Berdasarkan hasil analisis limbah cair teh hijau (Tabel 1), limbah cair teh hijau yang telah difermentasi 14 hari mengandung unsur hara nitrogen $(\mathrm{N})$ yang berpengaruh terhadap tinggi tanaman. Unsur nitrogen dapat memacu pembentukan asam-asam amino menjadi protein di dalam tubuh tanaman karet. Protein yang terbentuk digunakan untuk membentuk hormon pertumbuhan, yakni hormon auksin, giberelin, dan sitokinin. Ketiga hormon tersebut saling berperan dalam menunjang pertambahan tinggi tanaman dan adanya unsur hara kalium yang berfungsi sebagai aktifator enzim menyebabkan reaksi biosintesis hormon maupun protein lain dapat berlangsung cepat sehingga tanaman karet dapat tumbuh tinggi (Tjionger, 2006). Pertambahan tinggi tanaman tidak hanya dipengaruhi oleh unsur nitrogen. Unsur hara lain yang berperan dalam proses pertambahan tinggi tanaman diantaranya adalah fosfor $(\mathrm{P})$, seng $(\mathrm{Zn})$, besi $(\mathrm{Fe})$ dan mangan $(\mathrm{Mn})$.

Tabel 2. Rerata Pengamatan Pertumbuhan Bibit Karet

\begin{tabular}{|c|c|c|c|c|c|c|c|}
\hline Perlakuan & Tinggi & $\begin{array}{l}\text { Jumlah } \\
\text { Daun }\end{array}$ & Kehijauan & \multicolumn{3}{|c|}{ Bobot Kering (gr) } & Panjang \\
\hline Penyiraman & $\begin{array}{l}\text { Tanaman } \\
(\mathrm{cm})\end{array}$ & (Helai) & Daun & Akar & Batang & Daun & $\begin{array}{l}\text { Akar } \\
(\mathrm{cm})\end{array}$ \\
\hline $\begin{array}{l}\text { Air 1 Minggu } \\
\text { Sekali }\end{array}$ & $39,54 \mathrm{~b}$ & $11,29 a$ & $3,34 b$ & $3,40 b$ & $4,60 \mathrm{a}$ & $3,82 \mathrm{~b}$ & $47,98 \mathrm{a}$ \\
\hline $\begin{array}{l}\text { POC } 2 \text { Minggu } \\
\text { Sekali }\end{array}$ & $46,76 \mathrm{a}$ & $12,74 \mathrm{a}$ & $3,58 \mathrm{a}$ & $3,96 a$ & $4,72 \mathrm{a}$ & $4,86 \mathrm{a}$ & $48,42 \mathrm{a}$ \\
\hline $\begin{array}{l}\text { POC } 4 \text { Mingu } \\
\text { sekali }\end{array}$ & $44,16 a b$ & $12,04 \mathrm{a}$ & $3,49 \mathrm{ab}$ & $3,60 \mathrm{ab}$ & $4,20 \mathrm{a}$ & $4,64 a b$ & $39,70 \mathrm{a}$ \\
\hline $\mathrm{KK}(\%)$ & 8,92 & 8,6 & 3,86 & 10,15 & 19,15 & 13,61 & 12,88 \\
\hline
\end{tabular}

Keterangan: Angka rata-rata yang diikuti oleh huruf yang sama menunjukkan tidak berbeda nyata ada uji DMRT taraf $5 \%$.

$*$ = berbeda nyata;

** = berbeda sangat nyata; dan $\mathrm{tn}=$ berbeda tidak nyata 
Pengaplikasian pupuk organik cair limbah teh hijau menunjukkan bahwa tanaman yang diberi perlakuan penyiraman POC 2 minggu sekali memiliki rataan jumlah daun tertinggi dibandingkan dengan perlakuan penyiraman air 1 minggu sekali dan penyiraman POC 4 minggu sekali. Pupuk organik cair akan mempercepat pembentukan daun jika diaplikasikan dalam konsentrasi rendah namun dengan pemberian secara rutin. Pupuk organik cair akan memberikan hasil budidaya tanaman yang rendah apabila diberikan dengan konsentrasi tinggi namun beberapa kali pemupukan dalam masa tanam.

Pengaplikasian pupuk organik cair limbah teh hijau terdapat beda nyata. Nilai kehijauan daun antara perlakuan penyiraman air 1 minggu sekali dengan penyiraman POC 2 minggu sekali. Semakin sering penyiraman hasil fermentasi limbah cair teh hijau maka semakin tinggi kandungan unsur haranya. Maka dari itu semakin sering penyiraman hasil fermentasi limbah cair teh hijau maka kandungan unsur hara $\mathrm{N}$ yang terdapat pada tanaman akan semakin tinggi. Kelebihan unsur hara $\mathrm{N}$ pada tanaman dapat meningkatkan kadar klorofil pada tanaman. Unsur hara $\mathrm{N}$ memegang peranan penting sebagai penyusun klorofil, sehingga daun akan nampak berwarna lebih hijau. Dalam jaringan tanaman, nitrogen merupakan komponen penyusun berbagai senyawa esensial seperti protein, asam amino, amida, asam nukleat, nukleotida, koenzim, klorofil, sitosin, auksin dan komponen utama bahan kering yang berasal dari bahan protoplasma tanaman (Salisbury dan Ross, 1992).

Tren pertumbuhan bibit karet menunjukkan bahwa perlakuan penyiraman POC 2 minggu sekali lebih baik dan memiliki hasil yang tinggi dibandingkan dengan perlakuan penyiraman POC 4 minggu sekali dan penyiraman air 1 minggu sekali. Setelah aplikasi pupuk organik cair terdapat pertumbuhan yang lebih baik pada tinggi tanaman, jumlah daun, maupun nilai kehijauan daun. Hal ini disebabkan karena adanya titik puncak tumbuh tanaman.

Pengaplikasian pupuk organik cair limbah teh hijau berpengaruh nyata pada bobot kering daun dan terdapat pengaruh sangat nyata pada bobot kering akar, sedangkan respon bobot kering batang tidak berbeda nyata. Perlakuan penyiraman POC 2 minggu sekali memberikan pengaruh lebih tinggi dibandingkan dengan perlakuan penyiraman POC 4 minggu sekali dan penyiraman air 1 minggu sekali. Hal ini menunjukkan bahwa pupuk organik cair yang diberikan mampu memacu penambahan jumlah daun, klorofil dan luas daun. Meningkatnya luas daun berarti kemampuan daun untuk menerima dan menyerap cahaya matahari akan lebih tinggi sehingga fotosintat dan akumulasi bahan kering akan lebih tinggi pula pada setiap bobot bagian tanaman. Menurut Wijaya (2010) penambahan luas daun merupakan efisiensi tiap satuan luas daun melakukan fotosintesis untuk menambah bobot kering tanaman. Selanjutnya dikemukakan bahwa paling sedikit $90 \%$ bahan kering adalah hasil fotosintesis. Faktor lain yang mempengaruhi diantaranya ketersediaan unsur hara bagi tanaman selama pertumbuhan memiliki hubungan erat dengan bobot kering tanaman. Ratna (2002), mengemukakan bahwa apabila unsur hara tersedia dalam keadaan seimbang dapat meningkatkan pertumbuhan vegetatif dan bobot kering tanaman, akan tetapi apabila keadaan unsur hara dalam kondisi yang kurang atau tinggi akan menghasilkan bobot kering yang rendah. Menurut Sumarsono 
(2007), berat kering mencerminkan akumulasi senyawa organik yang berhasil disintesis tanaman dari senyawa anorganik (air, $\mathrm{CO}_{2}$ dan unsur hara) melalui fotosintesis.

Pada perlakuan penyiraman POC 2 minggu sekali menghasilkan panjang akar 48,42 cm, sedangkan pada perlakuan penyiraman POC 4 minggu sekali menghasilkan panjang akar $39,70 \mathrm{~cm}$. Berdasarkan kandungan unsur hara yang terdapat didalam POC dari limbah cair teh hijau yaitu unsur nitrogen yang berperan dalam pembentukan bagian vegetatif tanaman (akar). Hakim et al., (1986), yang mengatakan bahwa pemberian unsur hara nitrogen yang cukup akan merangsang pertumbuhan akar dan meningkatkan biomassa akar. Penyiraman pupuk organik cair 2 minggu sekali dipastikan unsur hara yang didapat tercukupi bagi akar untuk melakukan pemanjangan akar.

Menurut Wulandari et al (2011), bahwa tanaman yang memiliki nilai nisbah tajuk akar tinggi dengan biomassa total yang besar pada tanah subur secara tidak langsung menunjukkan bahwa akar relatif sedikit, cukup untuk mendukung pertumbuhan tanaman yang relatif besar dalam penyediaan air dan unsur hara serta ditambah lagi jika ada penambahan bahan organik seperti dari POC, sehingga nilainya akan menjadi lebih tinggi lagi. Nisbah tajuk akar yang seimbang merupakan ciri pertumbuhan yang normal. Informasi mengenai nisbah tajuk akar diperlukan untuk mengetahui keseimbangan antara pertumbuhan tajuk tanaman sebagai tempat terjadinya proses fotosintesis dengan pertumbuhan akar sebagai bidang serapan unsur hara dan air. Nilai nisbah tajuk akar yang tinggi menunjukkan pertumbuhan bagian pucuk tanaman lebih tinggi dibandingkan dengan pertumbuhan akarnya. Lebih besarnya biomassa tajuk dibandingkan dengan biomassa akar dapat memungkinkan terjadinya pengendalian penyerapan hara oleh tajuk. Tajuk akan meningkatkan penyerapan hara oleh akar secara cepat dan menggunakan hara tersebut dalam bentuk produk pertumbuhan (asam nukleat, protein, dan klorofil).

\section{KESIMPULAN}

Pemberian pupuk organik cair dari limbah cair teh hijau yang terfermentasi pada perlakuan penyiraman 2 minggu sekali dapat meningkatkan pertumbuhan tanaman karet, meliputi tinggi tanaman, kehijauan daun, berat kering akar dan daun tanaman karet.

\section{DAFTAR PUSTAKA}

Anonim, 2003. Panduan Teknis Budidaya Karet (Vademecum). PT Perkebunan Nusantara III. Medan. 97 hal.

Direktorat Jendral Perkebunan. 2014. Kriteria Benih Karet Yang Baik Dan Bermutu. http://ditjenbun.pertanian.go.id/tanhun/berita-253-kriteria- benihkaret-yang-baik-dan-bermutu.html. Diakses pada tanggal 12 Maret 2017.

Hakim, N., M.Y. Nyakpa, A. M. Lubis, S. G. Nugroho. 1986. Dasar-Dasar Ilmu Tanah. Unila. Lampung. 
Hanolo, W. 1997. Tanggapan Tanaman Selada Dan Sawi Terhadap Dosis Dan Cara Pemberian Pupuk Cair Stimulant. Jurnal Agrotropika 1(1):25-29.

Muningsih, Retno dan Susilawardani, 2015. Pengaruh Penggunaan Biofertilizer Untuk Meningkatkan Kesehatan Tanaman dan Pemecahan Pucuk Dorman pada Bibit Teh di PT Tambi. Agro-UPY, Volume 7. No.1, September 2015. Fakultas Agroteknologi, Universitas PGRI, Yogyakarta. ISSN: 19782276

Muningsih, Retno dan Gunawan Ciptadi, 2017. Potensi Limbah Cair Teh Hijau Sebagai Bahan Pupuk Organik. Agrin Vol 21 No. 2 Oktober 2017. Fakultas Pertanian, Universitas Jenderal Soedirman, Purwokerto

Peraturan Menteri Pertanian. 2011. No.70/Permentan/SR.140/10/2011 Tentang Pupuk Organik, Pupuk Hayati, dan Pembenah Tanah.

Purwati, MS. Pertumbuhan Bibit Karet (Havea brasiliensis L.) Asal Okulasi Pada Pemberian Bokashi dan Pupuk Organik Cair Bintang Kuda Laut. Jurnal Agrifor. Volume XII Nomor 1. Maret 2013. Hal 35-43

Ratna, D.I. 2002. Pengaruh Kombinasi Konsentrasi Pupuk Hayati Dengan Pupuk Organik Cair Terhadap Kualitas Dan Kuantitas Hasil Tanaman Teh (Camellia Sinensis (L.) O. Kuntze) Klon Gambung 4. Ilmu Pertanian 10 (2):17-25.

Salisbury. F. B dan Cleon W.ross, 1995. Fisiologi Tumbuhan. Sel: Air, Larutan Dan Permukaan. ITB Bandung. Hal 241.

Sumarsono. 2007. Analisis Kuantitatif Pertumbuhan Tanaman Kedelai (Soy Beans). Jurnal Nutrisi dan Makanan Ternak. Fakultas Peternakan. Universitas Dipenogoro. Semarang.

Taiz, L., and E. Zieger, 2006. Plant Physiology. Sinauer Associates. Inc. Publisher. Massachusetts. 792p

Tjionger, M. 2006. Pentingnya Menjaga Keseimbangan Unsur Hara Makro dan Mikro untuk Tanaman, Makasar.

Tumpal H. S., Siregar, dan Irwan Suhendri. 2013. Budi Daya \& Teknologi Karet. Penebar Swadaya. Jakarta

Wijaya Kelik, 2010. Pengaruh Konsentrasi dan Frekuensi Pemberian Pupuk Organik Cair Hasil Perombakan Anaerob Limbah Makanan Terhadap Pertumbuahan Tanaman Sawi (Brassica juncea L.). Skripsi. Fakultas 
Matematika dan Ilmu Pengetahuan Alam. Universitas Sebelas Maret. Surakarta. 55 hal.

Wulandari, A.S, I. Mansur, dan H. Sugiarti. 2011. Pengaruh Pemberian Kompos Batang Pisang terhadap Pertumbuhan Semai Jabon (Anthocephalus cadamba Miq.). Fakultas Kehutanan Institut Pertanian Bogor. Jurnal Silvikultur Tropika. Vol. 03 No. 01, Hal. 78-81. 